\title{
Rapid and Flash Tests: Indicator for Quality of HT-PEM Fuel
}

\section{Cells Batches?}

\author{
M. Rastedt ${ }^{1}$, J. Büsselmann ${ }^{1}$, V. Tullius ${ }^{1}$, P. Wagner ${ }^{1}$ and A. Dyck ${ }^{1}$ \\ ${ }^{1}$ DLR Institute of Networked Energy Systems, Carl-von-Ossietzky-Str. 15, D-26129 \\ Oldenburg, Germany \\ [*]Corresponding author: maren.rastedt@dlr.de
}

\begin{abstract}
In order to control the batch quality of membrane electrode assemblies (MEA), two new short tests have been developed. The first being a rapid test, composed of a start-up and break-in followed by initial characterization and has a test duration of about $65 \mathrm{~h}$, while the second is a flash test, which is reduced by the break-in, so that the maximum duration is $8 \mathrm{~h}$. These tests have been compared with classical accelerated stress tests like load cycling at high current densities and start/stop cycling. For the investigations presented in this publication, high temperature polymer electrolyte MEAs from two different suppliers were used. The extensive electrochemical characterisation clearly shows that the newly introduced fast tests can be used to check the batch qualities. In addition to the electrochemical investigations, the phosphoric acid content of all MEAs has been determined and ex situ micro-computed tomography analysis has been performed.
\end{abstract}

Keywords: High Temperature Polymer Electrolyte Membrane (HT-PEM), Accelerated Stress Test (AST), Load Cycling, Start/Stop Cycling, Degradation, Micro-Computed Tomography 


\section{Introduction}

High Temperature Polymer Electrolyte Membrane (HT-PEM) fuel cells have significantly improved in recent years, as evidenced by the reduction in degradation rates. More than ten years ago, Schmidt published data obtained with a Celtec®-P Series 1,000 MEA (Membrane electrode assembly) reporting a runtime of more than 18,000 hours and a degradation rate of $6 \mu \mathrm{V} \mathrm{h}^{-1}$ at current densities of $0.2 \mathrm{~A} \mathrm{~cm}^{-2}$ [1]. This result was confirmed by Oono's et al. investigations; at an operating temperature of $150{ }^{\circ} \mathrm{C}$, a long-term test at constant load of 0.2 $\mathrm{A} \mathrm{cm}^{-2}$ for 17,860 hours could be carried out [2]. Earlier this year Søndergaard et al. published results of thermally crosslinked PBI (phosphoric acid doped polybenzimidazole) HT-PEM fuel cells [3]. These new MEAs achieved degradation rates of only $1.4 \mu \mathrm{Vh}^{-1}$ on average at $160{ }^{\circ} \mathrm{C}$ and $0.2 \mathrm{~A} \mathrm{~cm}^{-2}$; this long-term test reached 13,000 hours. Between 1,000 and 9,200 hours of operations, the degradation rate was even lower: $0.5 \mu \mathrm{V} \mathrm{h}^{-1}$ [3]. The authors of this publication made similar observations with this type of MEA. A stable long term test showed degradation rates below $3 \mu \mathrm{V} \mathrm{h}^{-1}$ for $15,500 \mathrm{~h}$. After this period, the MEA exhibited a large voltage drop and reached end of test (EoT) after 16,080 h, parts of this experiment have been published in [4].

This shows very clearly that a considerable step was made in the direction of improving the durability above 40,000 hours required for the stationary applications [5]. A further problem is the confirmation of such lifetimes, as the long operation in the laboratory is neither feasible nor practicable by the industry. Several accelerated stress tests [6-8], such as load cycling [9$12]$, potential cycling $[13,14]$, hydrogen stoichiometry cycling [15] or start/stop cycling [12, 16-18], have been developed; however, a realistic life expectancy is also difficult to obtain with such tests. Søndergaard et al. reported that MEAs, which previously ran stable over 9,000 hours and exhibited low degradation rates, showed a sudden decline in performance. Søndergaard suggested also that the $\mathrm{H}_{3} \mathrm{PO}_{4}$ acid loss seems to be mainly responsible for the degradation of these MEAs [3]. Implementation of a joint quality assurance system is carried 
out within the framework of the project QUALIFIX supported by the German Federal Ministry for Economic Affairs and Energy (BMWi), with the participation of the component manufacturers. At the center of this project is the quality control of the MEA batches of various suppliers.

Four types of tests have been compared for this publication. Load cycling at high current densities and start/stop cycling have been performed and compared with two newly defined short-term tests. One of these new procedures is the rapid test, which consist of the complete MEA activation (start-up and break-in) followed by the initial characterization. The flash test represents the second short test, which is further reduced. This procedure is composed only of the start-up and initial characterization. With the help of these tests the respective batch qualities are to be determined in a much shorter time; approx. $65 \mathrm{~h}$ in case of the rapid test and maximum $8 \mathrm{~h}$ for the flash test. All four tests presented in this publication are carried out with MEAs from two suppliers; both were compared internally and between the manufacturers.

\section{Experimental}

All experiments presented in this paper have been performed with MEAs from two different manufacturers and are commercially available. These MEAs have been bought directly offthe-shelf in batches of minimum ten MEAs; no adaptions regarding the requirements of the conducted experiments were made to those MEAs. From each batch three have been randomly chosen for experimental investigation. The geometry of the active surface area of both MEA-types is $25 \mathrm{~cm}^{2}$ and phosphoric acid doped polybenzimidazole (PBI) has been used as membrane.

\subsection{Experimental setup}

The MEAs were investigated on different fuel cell test benches (inhouse engineering GmbH (Germany) and FuelCon AG (Germany)). At all test stations, cell compression units (CCU) 
were used to ensure constant nominal contact pressures of $0.75 \mathrm{MPa}$. Those CCUs have been equipped with 5-fold serpentine flow field bipolar plates for each test presented in this paper. The fuel cell test benches were supplied with hydrogen as fuel (with a stoichiometry $(\lambda)$ of $\lambda=1.5)$ as well as air as oxidant $(\lambda=2.0)$ during the main operation. While polarisation curves have been recorded via the test bench electronical loads, an external Potentiostat Modulab 2100A from Solartron Analytical (United Kingdom) has been used to carry out impedance spectroscopy, linear sweep and cyclic voltammetry.

\subsection{Fuel Cell Test Procedure}

After installing the single cell / MEA into the CCU several procedure steps were performed. These steps are defined in the following subsections (2.2.1 - 2.2.7) and the respective sequences of these steps are shown in Figure 1.

\subsubsection{Start-up}

During the heat-up process up to $120{ }^{\circ} \mathrm{C}$, the MEA was kept under a nitrogen atmosphere. When $120{ }^{\circ} \mathrm{C}$ was reached, the gas supply was switched to operating gases (hydrogen $(\lambda=1.5)$ as fuel and air $(\lambda=2)$ as oxidant). As soon as a voltage is present, a current density of $0.3 \mathrm{~A}$ $\mathrm{cm}^{-2}$ is approached step by step with a step size of $0.04 \mathrm{~A} \mathrm{~cm}^{-2} \mathrm{~min}^{-1}$. From the time when stable operation is reached, all further load changes are carried out with $0.2 \mathrm{~A} \mathrm{~cm}^{-2} \mathrm{~min}^{-1}$.

\subsubsection{Break-in}

Following the start-up phase, the current density was kept constant at $0.3 \mathrm{~A} \mathrm{~cm}^{-2}$ for 62 to 72 hours, the different break-in durations are caused by workflow-processes in the laboratory. During the break-in procedure, hydrogen and air were used as gas supply.

\subsubsection{Electrochemical Characterisation}


Following the start-up and break-in phase an initial electrochemical characterisation was performed. The identical procedure was repeated at the end of test after 500 hours of operation. The following steps are included within this characterisation:

(i) Recording of polarisation curves and electrochemical impedance spectroscopy (EIS) under operation gas supply (fuel: $\mathrm{H}_{2}$, oxidant: air)

(ii) Changing of oxidant gas supply to oxygen $(\lambda=9.5)$, while hydrogen was kept as fuel $(\lambda=1.5)$,

(iii) A new recording of polarisation curves and electrochemical impedance spectroscopy (fuel: $\mathrm{H}_{2}$, oxidant: $\mathrm{O}_{2}$ )

(iv) Changing of gas supply to $\mathrm{H}_{2} / \mathrm{N}_{2}$ followed by execution of cyclic and linear sweep voltammetry measurements (CV and LSV)

(v) Reset to primary reactant gas supply: hydrogen as fuel $(\lambda=1.5)$ and air as oxidant $(\lambda=2)$ (see (i))

The individual steps are described in detail in the following sections:

\subsubsection{Polarisation curves}

After a conditioning time of $10 \mathrm{~min}$ at $0.3 \mathrm{~A} \mathrm{~cm}^{-2}$, the starting current density was set to $0.2 \mathrm{~A} \mathrm{~cm}^{-2}$, increased to $1.0 \mathrm{~A} \mathrm{~cm}^{-2}$, decreased to open circuit potential (OCP), again increased to $1.0 \mathrm{~A} \mathrm{~cm}^{-2}$ and finally back to $0.3 \mathrm{~A} \mathrm{~cm}^{-2}$ in $0.5 \mathrm{~A}$ steps, each step being held for $30 \mathrm{~s}$. A voltage value of $0.4 \mathrm{~V}$ has been defined as lower limit. These polarisation curves were recorded directly through the fuel cell test station.

\subsubsection{Electrochemical impedance spectroscopy (EIS)}

EIS measurements were performed in potentiostatic mode with the application of a sinusoidal voltage with perturbation amplitude of $10 \mathrm{mV}$ r.m.s. within the frequency range from $100 \mathrm{kHz}$ to $100 \mathrm{mHz}$. For these EIS investigations, an external potentiostat (Modulab 2100A from 
Solartron Analytical, UK) was connected to the test cell. The measurements were conducted at five different current densities: $0.03 ; 0.1 ; 0.2 ; 0.3$ and $0.4 \mathrm{~A} \mathrm{~cm}^{-2}$.

\subsubsection{Cyclic voltammetry}

For the cyclic voltammetry investigations, nitrogen with a gas flow of $0.1 \mathrm{NL} \min ^{-1}$ was passed through the cathode, used as the working electrode. The anode was designated counter

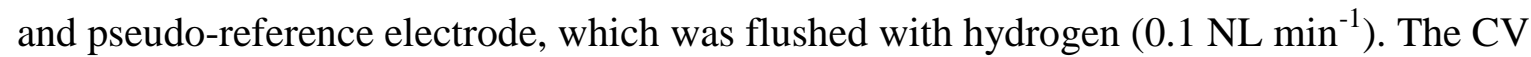
scan started from $0.05 \mathrm{~V}$ up to $1.0 \mathrm{~V}$ with a rate of $100 \mathrm{mV} \mathrm{s}^{-1}$. For each measurement seven CV scans have been recorded, while the $6^{\text {th }}$ scan was used for the evaluation. As for the EIS measurements, the Modulab 2100A was used as an external potentiostat for performing the CV measurements.

\subsubsection{Linear Sweep Voltammetry}

Likewise the CV measurements, the linear sweep voltammetry has been performed with nitrogen flow through the working electrode (cathode) and hydrogen supply on the anode, which was employed as counter and pseudo-reference electrode. In contrast to cyclic voltammetry, a flow of $0.3 \mathrm{NL} \mathrm{min}^{-1}$ was used for both gases during LSV. The LSV measurements were performed with a potential sweep between the initial rest potential and $0.5 \mathrm{~V}$ using a scan rate of $2 \mathrm{mV} \mathrm{s}^{-1}$. These measurements were also carried out with the external potentiostat.

\subsubsection{Rapid Test}

The rapid test is a shortened test that consists of the start-up (Section 2.2.1) and the break-in (Section 2.2.2) with subsequent electrochemical characterisation (Section 2.2.3 (i), (iv), (v)), but no further test protocol like load (Section 2.2.6) or start/stop-cycling (Section 2.2.7). 


\subsubsection{Flash Test}

For the flash test, the rapid test was reduced by the break-in, which means that the initial characterisation (Section 2.2.3 (i), (iv), (v)) was executed immediately after the start-up (Section 2.2.1).

\subsubsection{Load-Cycling}

For the load cyclisation operation, the MEA first performed the above-described start-up (Section 2.2.1) and break-in procedures (Section 2.2.2); followed by the initial characterisation (Section 2.2.3 (i)-(v)). As operational gases hydrogen $(\lambda=1.5)$ and air $(\lambda=2)$ were used. The test duration of the protocol is 500 hours with a cyclic load change between 0.6 and $1.0 \mathrm{~A} \mathrm{~cm}^{-2}$ :

(i) 4 min @ $0.6 \mathrm{~A} \mathrm{~cm}^{-2}$

(ii) $16 \min @ 1.0 \mathrm{~A} \mathrm{~cm}^{-2}$

This results in 1100 cycles with duration of $20 \mathrm{~min}$. A daily polarisation curve between OCP (open circuit voltage) and 1.0 $\mathrm{A} \mathrm{cm}^{-2}$ under hydrogen/air $(\lambda=1.5 / 2.0)$ has been performed. After 500 hours of load cycling operation, the tests have been ended after the final characterisation (Section 2.2.3 (i)-(v)).

\subsubsection{Start/Stop-Cycling}

With help of the start-up (Section 2.2.1) and break-in (Section 2.2.2) the MEAs have been prepared and activated for the start/stop-cycling. After this activation, the initial electrochemical characterisation was performed (Section 2.2.3). Following this characterisation, which was also marked as BoL, the test protocol was started. The start/stop cycling initiated with a 12 hours start-up phase in which the test sample is operated at a constant load of $0.3 \mathrm{~A} \mathrm{~cm}^{-2}$ at $160{ }^{\circ} \mathrm{C}$. After the start-up phase, the MEA was shut down in a controlled manner. For this purpose, the cell temperature is first lowered to $120{ }^{\circ} \mathrm{C}$. When 
$120{ }^{\circ} \mathrm{C}$ is reached, the cell is switched to the currentless mode and the operating gases are driven out by a nitrogen purge. In the meantime, the CCU is further cooled to an idling temperature of $30^{\circ} \mathrm{C}$. It could be seen that after about $3 \mathrm{~h}$ the targeted holding temperature of $30{ }^{\circ} \mathrm{C}$ was reached. The entire stop phase is held for $12 \mathrm{~h}$, after which the test cell was started up as described under Section 2.2.1. After $500 \mathrm{~h}$ of operation, which resulted in 20 complete start/stop-cycles (12 h start/12 h stop), the entire final characterisation (Section 2.2.3) had been performed.

\subsection{Determination of Phosphoric Acid Content}

In order to determine the phosphoric acid content ante- and post-mortem, three samples of each tested MEA have been cut with help of a standard punching tool with a diameter of $8 \mathrm{~mm}$. These samples have been separated to their single layer and stirred in a mixture of $30 \%$ acetone and $70 \%$ of distilled water at room temperature for $30 \mathrm{~min}$. After removing the sample parts from the mixture, this solution was titrated with $0.1 \mathrm{M}$ sodium hydroxide and use of the automatic titrator TitroLine alpha plus (SI Analytics, Germany) to determine the acid content.

\subsection{Micro-Computed Tomography}

The micro-computed tomography ( $\mu$-CT) examinations enable a non-destructive view into HT-PEM fuel cells. These investigations have been performed ex situ ante- and post-mortem with MEAs and have been carried out with a micro-computed X-ray tomography system (Skyscan 1172 Desktop-Micro-CT, Bruker, Belgium). With the help of a hole-puncher, samples were cut from the MEAs. In order to achieve a good resolution, the size of these samples was set 4 to $5 \mathrm{~mm}$.

The examination using the $\mu-\mathrm{CT}$ consists of three essential steps:

Step 1: Scan,

Step 2: Reconstruction, 
Step 3: Image generation \& analysis.

During the scan, several radiographs of the sample have been taken at different angles.

The collected radiographs have been merged into three dimensional representations / image volumes through extensive computer-assisted image reconstruction by back projection. With help of the software Dataviewer and $C T_{V o x}$ representative 2D- and 3D-image could be generated. In addition, the thickness values of all single MEA layers have been calculated from ten values of five sagittal or coronal 2D images by Dataviewer.

The settings used for these investigations are listed in Table 1.

\section{Results and Discussion}

\subsection{In situ Electrochemical Characterisation}

The performance results of the rapid (Figure 2 and 3, see Section 2.2.4), load cycling (Figure 4 and 5, Section 2.2.6) and start/stop-cycling (Figure 6 and 7, Section 2.2.7) tests are presented in Figure 2 to 7.

Figure 2 and 3 show the voltage as function of time of the rapid test, as described under Section 2.3.4, of three MEAs from provider A and B respectively. The three MEAs shown are each made up of one batch. A zoom of the first three operation hours is included in the images.

While in the case of the MEAs type A there is an increase in the voltage values in the first minutes, which subsequently drops again, the performance of the MEAs type B increases. Furthermore, the voltage characteristics of the MEAs B.1, B.2 and B.3 are nearly equal. In the case of the three MEAs of the manufacturer A, there are clear distinctions between the voltage values. While MEA A.2 and A.3 show similar values, A.1 represents an outlier. In addition, the batch quality can be estimated within the approx. $65 \mathrm{~h}$ rapid test, but this is also already possible in the first 3-4 hours as the respective zoom proves; this corresponds to the flash test (see Section 2.2.5). 
Figures 4 and 5 show the results of load cycling tests, which last $500 \mathrm{~h}$ each. Load cycling was carried out under identical test conditions for the MEAs A.7 - A.9 and B.7 - B.9. All six MEAs undergo continuous degradation. The MEAs of Type A have significantly higher degradation rates as shown in Table 2 and Figure 4. MEA A.7 shows the highest degradation rates for all three investigated current densities. Towards the end of the test, the voltage at $1.0 \mathrm{~A} \mathrm{~cm}^{-2}$ also drops below the $170 \mathrm{mV}$ limit of the test stand. From this limit, the electronic load is no longer technically capable of operating. The load current is then lowered downwards from this point, so that the voltage of the MEA is artificially kept at least $170 \mathrm{mV}$. Nevertheless, the degradation of the MEA is still progressing. In order to keep the voltage above $170 \mathrm{mV}$, the applied current density decreased continuously. The determination of the degradation rates always refers to areas with a constant current for reasons of comparability. The voltage profile of the MEAs A.8 and A.9 is not equivalent to the one of A.7 (Figure 4), the performance of this three MEAs differ a lot. As mentioned above, the respective three MEAs are from one batch. A.7 and B.7 show results, which have been gained directly after delivery of the respective batch. While A.7 reveals high degradation rates, MEA B.7 shows as well as B.8 and B.9 - a much smaller degradation rate under identical test conditions. The three MEAs of type B show an almost identical behavior, confirming the results of the rapid tests, as clearly visible in Figure 5. Only in case of MEA B.9 the test was stopped after approx. $460 \mathrm{~h}$ of operation due to a test station failure. As previously mentioned, A.7 and B.7 were tested immediately after delivery while A/B.8 and A/B.9 were stored before their use. While the different storage times of the MEAs of one batch in case of manufacturer B do not seem to have any great influence, the different age of the A-MEAs could be a reason for the significantly different performance.

The results of tests performed under start/stop-cycling conditions are presented in Figure 6 and 6. The voltage profiles of the MEAs A.10 and A.11 are showing quite different behaviors during the stop-phases at start of the test procedure. The starting voltage value of MEA A.11 
is higher than the initial voltage of A.10. However, this change during the start/stop-operation, MEA A.10 reveals the better performance at EoT. These observations coincide with the results of the load cycling, since the voltage developments of the MEA type A differ from each other in both test types (Figure 4 and 6). While consulting the voltage losses (Table 2), the degradation rate of A.11 is higher than the ones of the MEAs exposed to load cycling conditions; but this does not apply in the case of A.10. These differences in performance indicate a possible lack of consistent quality regarding the production of MEAs of type A. On the other hand, the MEAs type B show a more uniform behavior (Figure 7). MEA B.12 has a high OCP (open circuit potential) value at the beginning of each stop phase, but apart from that, MEA B.12 shows the same pattern as B.10 and B.11. The degradation rates of the MEAs type B are fairly moderate compared with the MEAs from provider A. While MEA B.10 and B.12 reveal quite similar performance behavior, B. 11 represents a positive outlier including the highest starting voltage value and lowest degradation rate (see Table 2). One essential aspect is apparent: The significant differences in performance between manufacturers. These differences could already be shown in the previous load cycling. In Figure 8 to 13, several polarisation curves under hydrogen and air supply at begin of test are presented. Figure 8 and 9 show a representative of each test performed (rapid, flash, load cycling and start/stop cycling tests) in order to compare the results of this study. In Figure 10 and 11, the BoL UI curves of all MEAs, which were used for the rapid tests or for the load or start/stop cycling, are shown. In addition, the direct comparison of the rapid and flash tests is presented in Figure 12 for supplier A, while Figure 13 shows the polarisation curves of provider B. The MEAs shown in Figure 8 are derived from two different batches. On one hand, MEA A.1, A.4 and A.9 are from one batch and the associated polarisation curves lie close together. On the other hand, MEA A.7 comes from another batch and represents an outlier in this composition. But even if the outlier is from another batch, batches of consistent quality are desirable. 
When considering the polarisation curves in Figure 9, it should be pointed out that these MEAs come from a total of three batches. While MEA B.2 (rapid test) and B.5 (flash test) are from the same batch and the polarisation curves are almost covering, the MEA B.8 and B.11 are from another two batches. The shape of the polarization curves are quite similar and do not show a large variance even with the MEAs of all three batches. This low scatter is also confirmed by the MEAs of type B from Figure 11. The low performance differences across three batches are a significant quality feature.

In a direct comparison, it is noticeable that the polarisation curves of the provider A are more scattered compared to the IV-curves of manufacturer B, as shown in Figure 10. In order to exclude the influence of different batches, only the MEAs of the two short tests are shown in Figures 12 and 13, which originate from one batch respectively. It can clearly be seen that the dispersion of the MEAs of the provider A is significantly greater than for the MEAs of type B; these show an almost congruently behavior. Even if MEA A.1 is declared as an outlier, the differences in the A-MEAs are greater than those of the MEAs of the manufacturer B. The results of the polarisation curves prove the observations of the voltage curves shown in Figure 2 to 7.

In addition to the polarisation and performance curves, the electrochemical active surface area (EASA) was determined at the beginning of the respective tests (see Figure 14 and 15). Two aspects are immediately apparent. The MEAs of the manufacturer A have significantly higher EASAs than the MEAs of type B. Furthermore, it is striking that the EASAs of the individual MEAs of manufacturer A have very different values, whereas the MEAs of provider B have similar electrochemical active surface areas; the variance of the values of provider B (Figure 15) is much lower than that of the provider A (Figure 14)). Despite the lower EASA, the MEAs of Type B show the better performance as shown in Figures 2 to 13. 


\subsection{Phosphoric acid content of MEA}

In addition to the investigations performed on the test stand, the phosphoric acid content of the used MEAs from provider B was determined. Due to the good performance, the supplier B's MEAs were selected for this procedure. The results are presented in Figure 16.

The phosphoric acid concentrations of the MEAs that have undergone the rapid, flash or load cycling tests are compared with the respective concentrations of the BoL MEAs. It is apparent that the $\mathrm{H}_{3} \mathrm{PO}_{4}$-content of the MEAs significantly decreases by $32 \%$ to even $57 \%$ after the tests. An average of $35 \%$ of the original acid concentration has been lost during the start-up procedure and the initial characterisation; this corresponds to the flash test. The break-in leads to an increase in the acid loss by a further $\sim 10 \%$, combined this equates to the rapid test. The additional load cycling conditions adds another $5 \%$ of phosphoric acid loss. Given the fact that load cycling is an AST for membrane degradation; the small contribution to phosphoric acid loss is surprising. Benicewicz et al. published a comparative study of the different phosphorous acid losses of load cycling conditions with fuel cell tests under steadystate conditions (constant load conditions with $0.2 \mathrm{~A} \mathrm{~cm}^{-2}$ ) in their durability investigations of HT-PEM fuel cells. While they observed a total acid output of

$7.6 \mathrm{ng} \mathrm{cm}^{-2} \mathrm{~h}^{-1}$ for the inserted MEAs with para-PBI membranes at constant loads, the loss under load cycling conditions almost tripled (21.28 $\left.\mathrm{ng} \mathrm{cm}^{-2} \mathrm{~h}^{-1}\right)$ [19]. Benicewizc's observations were confirmed by Pilinski's investigations [20]. Therefore it needs to be pointed out, that the load cycling conditions presented in their study differ from the test conditions presented in this paper and further investigations under similar test conditions are required to further examine the present observations. 


\subsection{Ex situ Micro-Computed Tomography Investigations}

A comparison of the 3D volume images of representatives of each test procedure and the associated ante-mortem MEAs of the respective batch are shown in Figure 17 (MEA-type A) and 18 (MEAs of provider B).

In the case of manufacturer A, the MEAs, which have passed the rapid, flash or start/stop cycling tests, are from the same batch; therefore these MEAs have the identical ante-mortem counterpart. The MEA from the load cycling procedure belongs to another batch, thus an additional corresponding BoL-MEA is shown. All pristine MEAs are characterised by their mirror symmetry with the membrane as the center. This mirror symmetry is also largely retained after the respective test. Only the examination of the load cycling BoL MEA reveals that both catalyst layers exhibit slight irregularities as well as condensation and thinning. And the EoL MEA of this test shows defects, as seen in the image of the cathode catalyst layer, as well as delamination of the central layers (Figure 17).

The results obtained with the $\mu$-CT investigations correspond to those of the polarisation curves (Figure 8), where the load cycling MEA is the negative outlier. If the layer thickness analyses (the results are listed in Table 3) are added, the observations from the threedimensional $\mu$-CT images are confirmed. The membrane from Batch 1 is quite stable and has an average thickness of approx. $70 \mu \mathrm{m}$, even after the respective test carried out. The only exception is the start/stop cycling MEA, which shows a slight decrease in the layer thickness. The membrane of the batch 2 also has similar layer thicknesses before and after the load cycling procedure; the membrane stayed nearly unchanged [21].

However, these membranes are markedly thinner $(55 \mu \mathrm{m})$ at begin of life than the membranes of batch $1(68 \mu \mathrm{m})$. In addition to the slight decrease in the membrane thickness during start/stop cycling, an increase in the anodic catalyst density can also be observed.

In the case of producer B, the MEAs used are from three different batches, as already 
described above. In contrast to manufacturer A, the MEAs of provider B are $>30 \%$ thicker, due to the used woven gas diffusion layers (GDL), which can be seen clearly in Figure 17. Due to the interwoven structures of the GDL, splinters, like small fingers, can be seen in the catalyst layer; these tailings are still preserved at EoT (Figure 18). Furthermore, as with the supplier A, a mirror symmetry before and after the respective tests can be observed for the type B MEAs. This is also confirmed by the layer thickness analyzes; the results are listed in Table 3. The only slight structural changes are visible after the load cycling test. A partial detachment of the catalyst layer from the GDL can be observed (see arrow, Figure 18). While White et al. observed wave formation in the membrane under conditions with $100 \%$ relative humidity [22], corrugation within the catalyst layers could be detected under dry test conditions of the study presented here. In addition, the membrane of the MEA, which has been tested under load cycling conditions, showed a slight shrinking after 500 hours of operation (Table 3). This is in conjunction with the highest phosphoric acid loss, presented in Figure 15.

\section{Conclusions}

The results of the measurements listed and explained in this paper provide three major conclusions. First of all, the load cycling and start/stop cycling test procedures provide clear results on the respective stability of the MEAs used. The MEAs show clear differences in performance losses at the end of the two test procedures mentioned above.

The second finding is the differences in MEA quality between the different manufacturers. Provider A supplied MEAs that survive the short test conditions shown in this publication. However, the individual MEAs reacted quite differently to the test procedures used. If these MEAs are used in a fuel cell stack, the overall performance is severely impaired and possible better single cells in the stack are affected. In the case of the manufacturer B, the MEAs have consistently good results. Even after exposure to the test procedures, the MEAs of Type B 
show hardly any scatter in the voltage traces. The stable performance of the MEAs points to long-term service life.

These findings on different stability during the accelerated aging test and differences in quality between manufacturers provide the third conclusion. As can be seen in the data of load cycling and start/stop cycling, deficiencies (which have clearly occurred after stress) are already evident in the running-in period by means of gaps in the voltage curves. The flash tests have not yet confirmed this finding due to their extremely short trial period. On the other hand, the rapid tests have confirmed the notion that there are quality differences between manufacturers A and B. Furthermore, it became clear that the rapid tests are unnecessarily extended in their duration, which gives the third realisation that a few hours of operation are sufficient to define quality requirements. The necessary duration deviates from manufacturer to manufacturer, but can be reliably determined by repeating the tests listed here. An extended flash test (start-up and three hours of operation at $0.3 \mathrm{~A} \mathrm{~cm}^{-2}$ followed by the initial characterisation) would be sufficient to examine the quality of a batch.

\section{Acknowledgements}

The authors would like to thank the German Federal Ministry for Economic Affairs and Energy (BMWi) for supporting and funding the project QUALIFIX (SC: 03Et6046A) in which the results presented here have been gained.

\section{List of Symbols}
A Ampere
$\mathrm{H} \quad$ Hertz
I Current density / $\mathrm{A} \mathrm{cm}^{-2}$
M molar
m Meter
min Minutes
NL Norm liters 
V Voltage

$\lambda \quad$ Stoichiometric factor

\section{List of abbreviations}

AST Accelerated stress test

BMWi German Federal Ministry for Economic Affairs and Energy

BoL Begin of life

CCU Cell compression units

CV Cyclic voltammetry

EASA Electrochemical active surface area

EIS Electrochemical impedance spectroscopy

EoT End of test

HT High temperature

LSV Linear sweep voltammetry

MEA Membrane electrode assembly

OCP Open circuit potential

PEM Polymer electrolyte membrane

PBI Phosphoric acid doped polybenzimidazole

$\mu$-CT Micro-computed tomography

\section{References}

[1] T.J. Schmidt, ECS Trans. 2006, 1, 8, 19.

[2] Y. Oono, A. Sounai, M. Hori, J. Power Sources 2012, 210, 366.

[3] T. Søndergaard, L.N. Cleemann, H. Becker, D. Aili, T. Steenberg, H.A. Hjuler, L. Seerup, Q. Li, J.O. Jensen, J. Power Sources 2017, 342, 570.

[4] M. Rastedt, F.J. Pinar, P. Wagner, H.R. Garía, T.Steenberg, H.A. Hjuler, M. Paidar, K. Bouzek, ECS Trans. 2016, 75, 14, 301.

[5] N. Garland, T. Benjamin, J. Kopasz, ECS Trans. 2007, 11, 1, 923. 
[6] F.N. Büchi, T.J. Schmidt, J. Electrochemical Society 2015, 162, 12, F1367.

[7] S.S. Araya, F. Zhou, S. Thomas, S.K. Kar, International Journal of Hydrogen Energy 2016, 41, 46, 21310.

[8] Y. Lu, H.T. Loh, A.C. Brombacher, E.D. Ouden, International Journal of Production Economics 2000, 67, 1, 17.

[9] M. Rastedt, V. Tullius, J. Büsselmann, D. Schonvogel, P. Wagner, A. Dyck, ECS Trans. 2017, 80, 8, 3.

[10] R.L. Borup, R. Mukundan, J. Fairweather, D. Spernjak, D. Langlois, J. Davey, K. More, K. Artyushkova, ECS Trans. 2013, 58, 1, 945.

[11] Y. Jeon, S.M. Juon, H. Hwang, J. Park, Y. Shul, Electrochimica Acta 2014, 148, 15.

[12] Y. Jeon, H. Na, Hy. Hwang, J. Park, Ho. Hwang, Y. Shul, International Journal of Hydrogen Energy 2015, 40, 3057.

[13] R.L. Borup, J.R. Davey, F.H. Garzon, D.L. Wood, M.A. Inbody, J. Power Sources 2006, 163,76 .

[14] P. Zihrul, I. Hartung, S. Kirsch, G. Huebner, F. Hasché, H.A. Gasteiger, J. Electrochemical Society 2016, 163, 6, F492.

[15] R. Taccini, T. Chinese, M. Boaro, International Journal of Hydrogen Energy 2016, $42,3,1875$.

[16] A. Lamibrac, G. Maranzana, J. Dillet, O. Lottin, S. Didierjean, J. Durst, L. Dubau, F. Maillard, M. Chatenet, Energy Procedia 2012, 29, 318.

[17] A. Kannan, A. Kabza, J. Scholta, J. Power Sources 2015, 277, 312.

[18] M. Rau, A. Niedergesäß, C. Cremers, S. Alfaro, T. Steenberg, H.A. Hjuler, Fuel Cells 2016, 16, 5, 577 .

[19] S. Yu, L. Xiao, B.C. Benicewicz, Fuel Cells 2008, 08, 3-4, 165.

[20] N. Pilinski, M. Rastedt, P. Wagner, ECS Trans. 2015, 69, 17, 323. 
[21] F. Zhou, S.J. Andreasen, S.K. Kar, International Journal of Hydrogen Energy 2015, 40, 2833.

[22] R.T. White, F.P. Orfino, M.E. Hannach, O. Luo, M. Dutta, A.P. Young, E. Kjeang, J. Electrochemical Society 2016, 163, 13, F1337. 
Figures

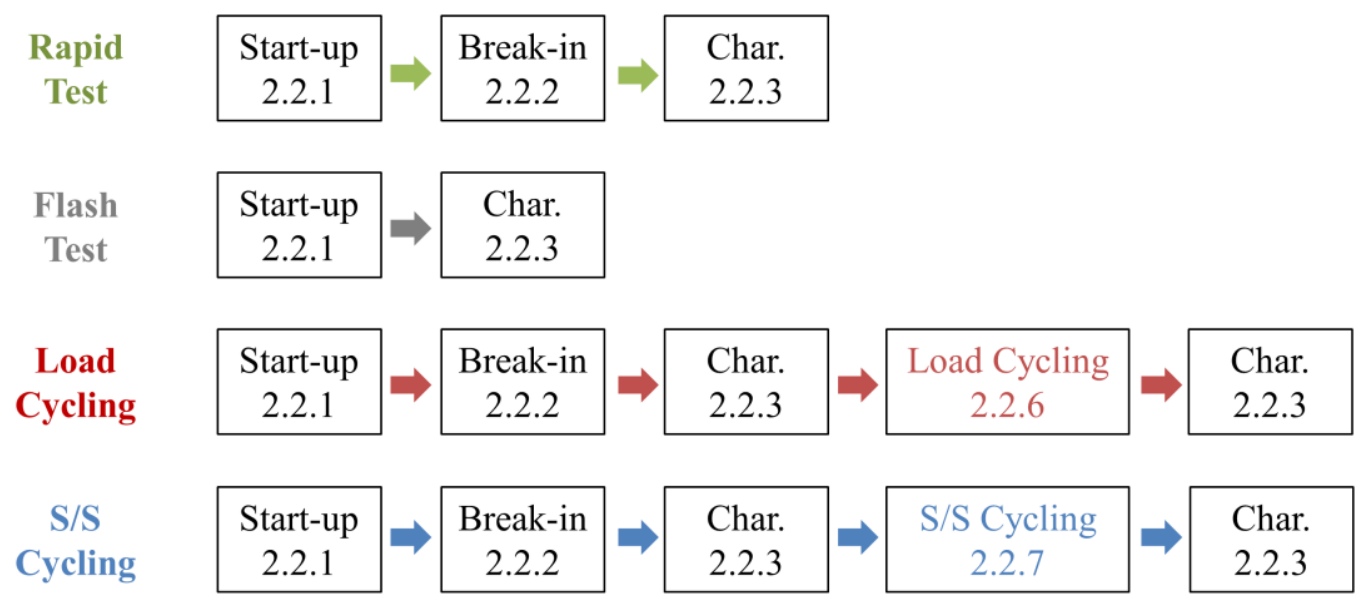

Figure 1: Flow chart of four test procedures: Rapid test, flash test, load cycling and start/stop cycling.

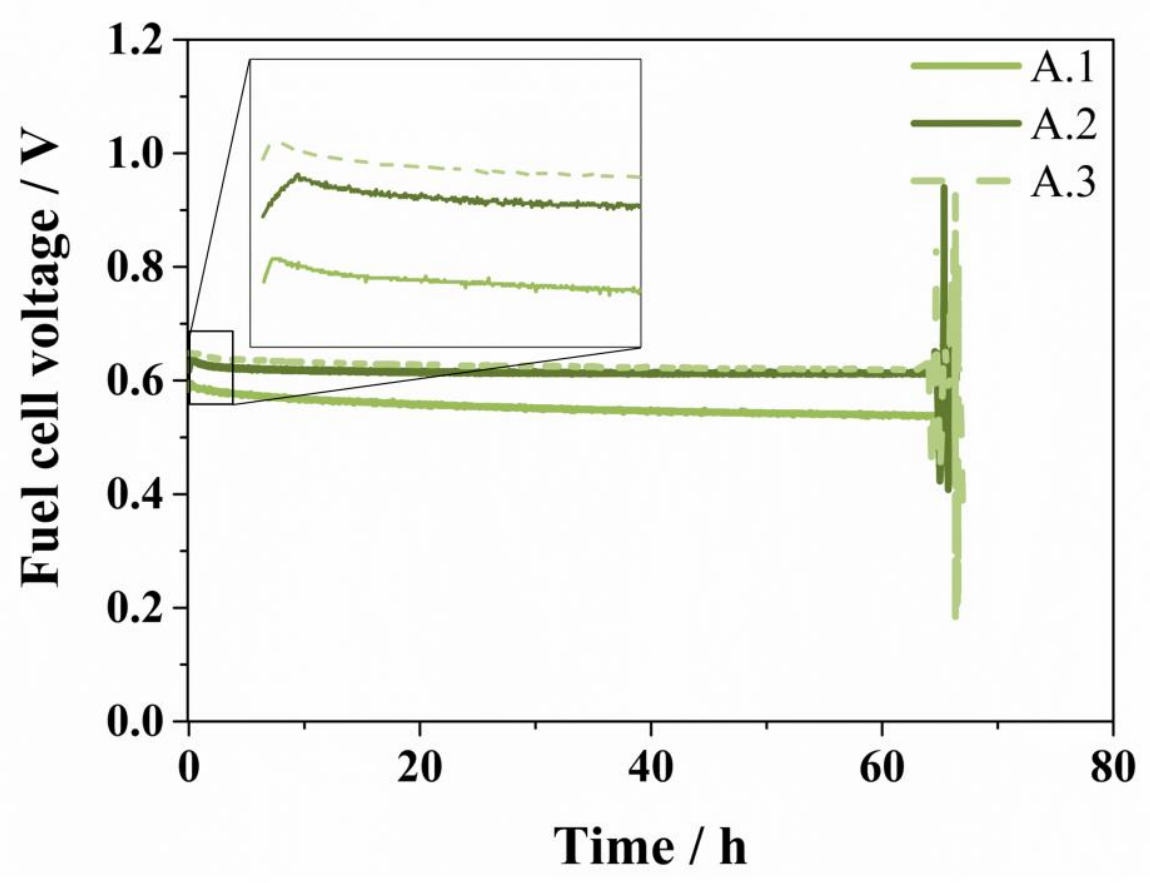

Figure 2: Voltage as function of time, rapid test, manufacturer A. 


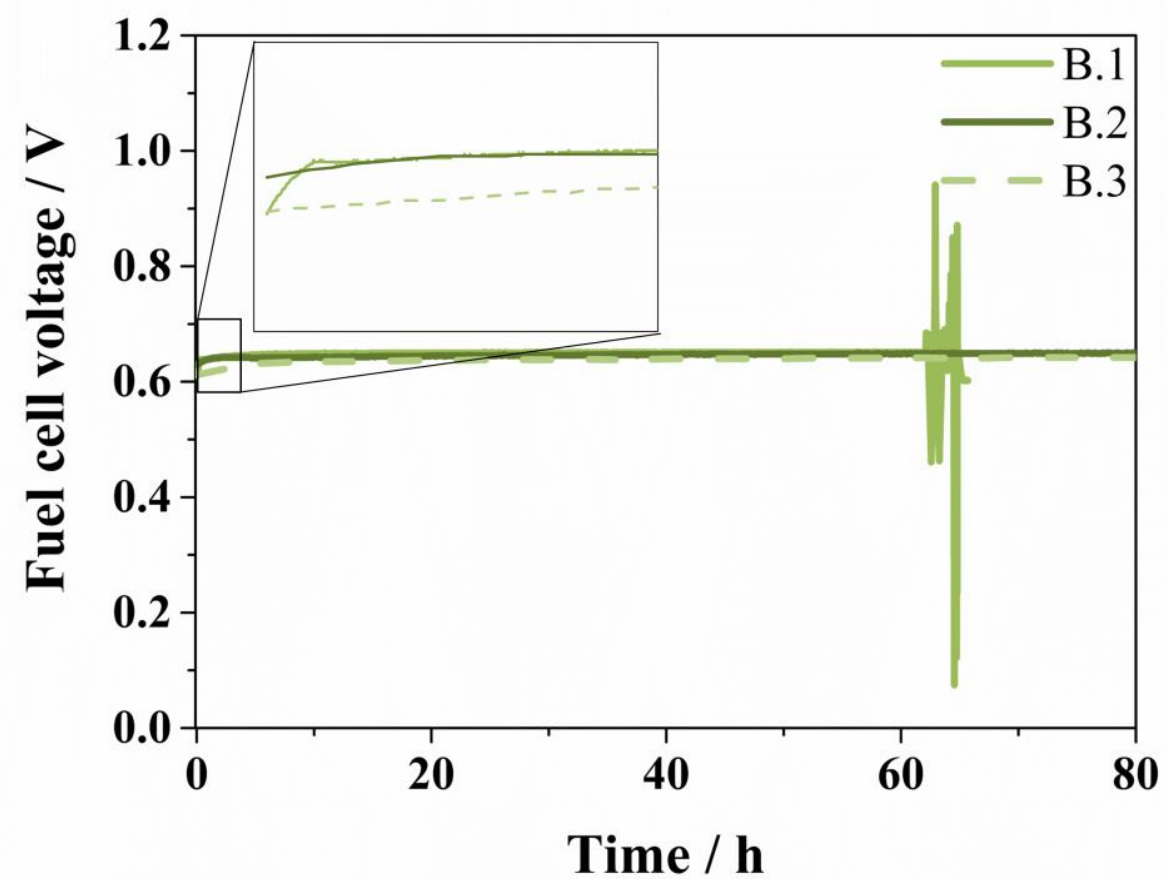

Figure 3: Voltage as function of time, rapid test, manufacturer B.

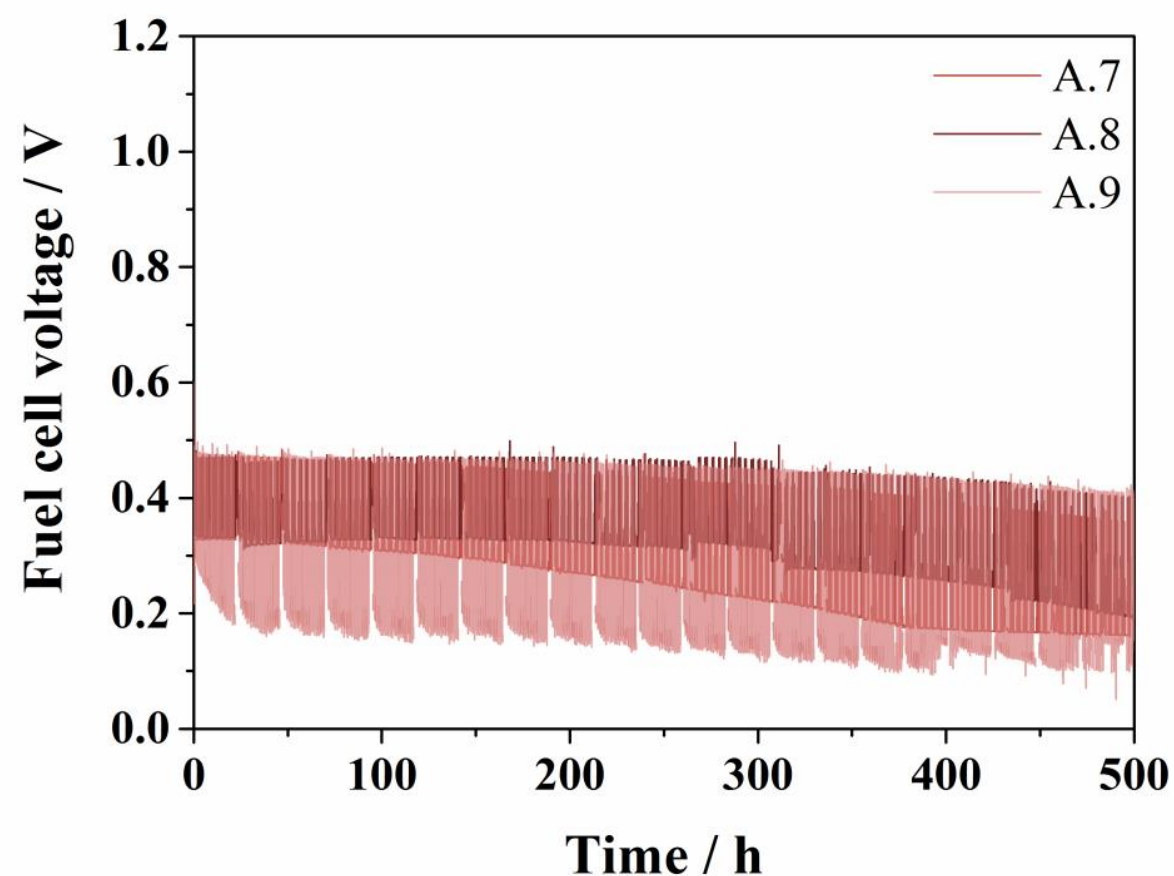

Figure 4: Voltage as function of time, load cycling test, manufacturer A. 


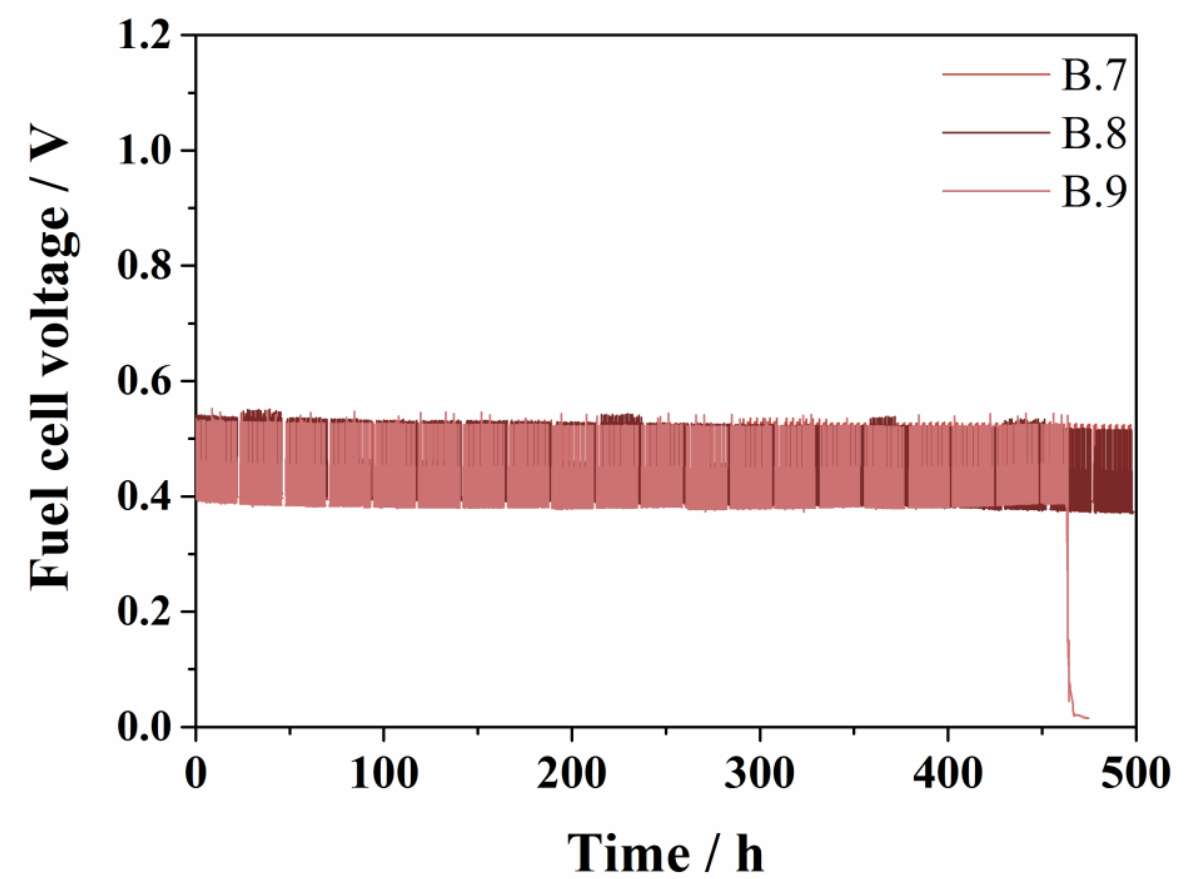

Figure 5: Voltage as function of time, load cycling test, manufacturer B.

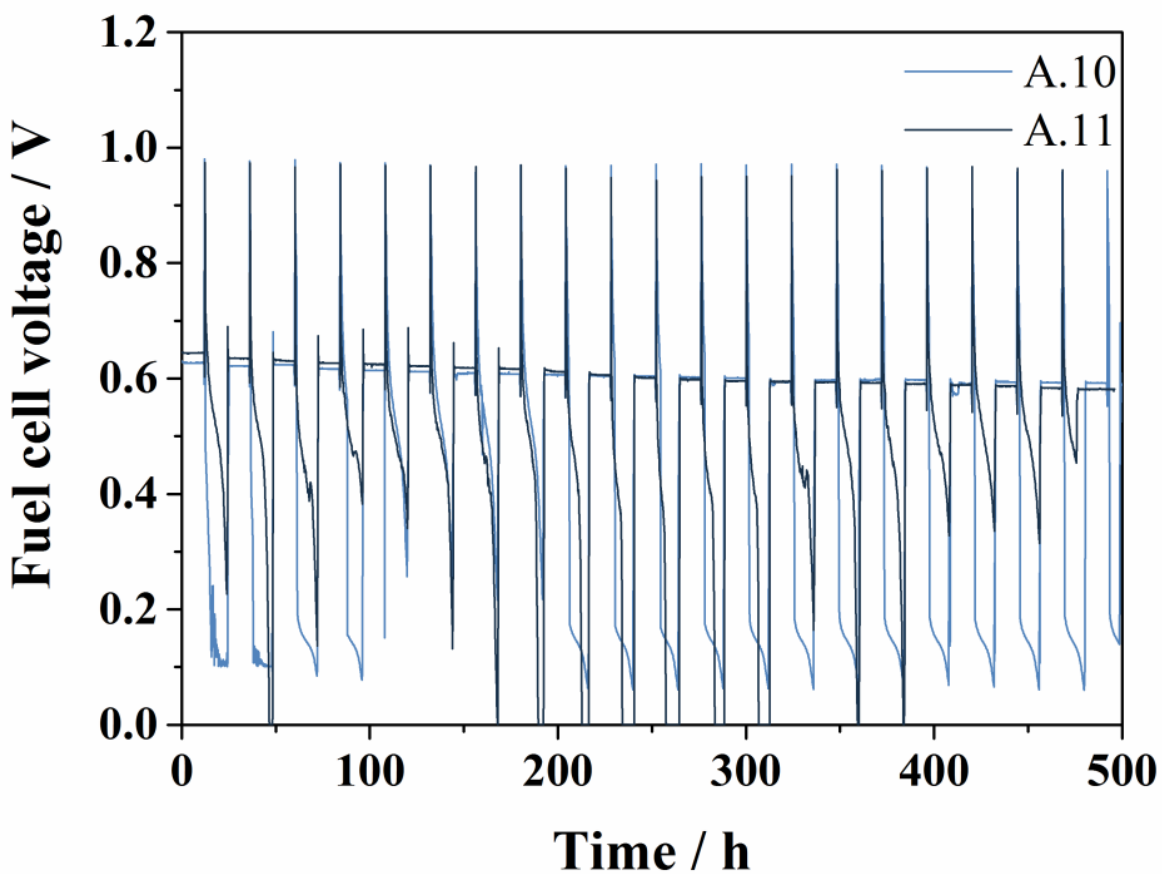

Figure 6: Voltage as function of time, start/stop cycling test; manufacturer A. 


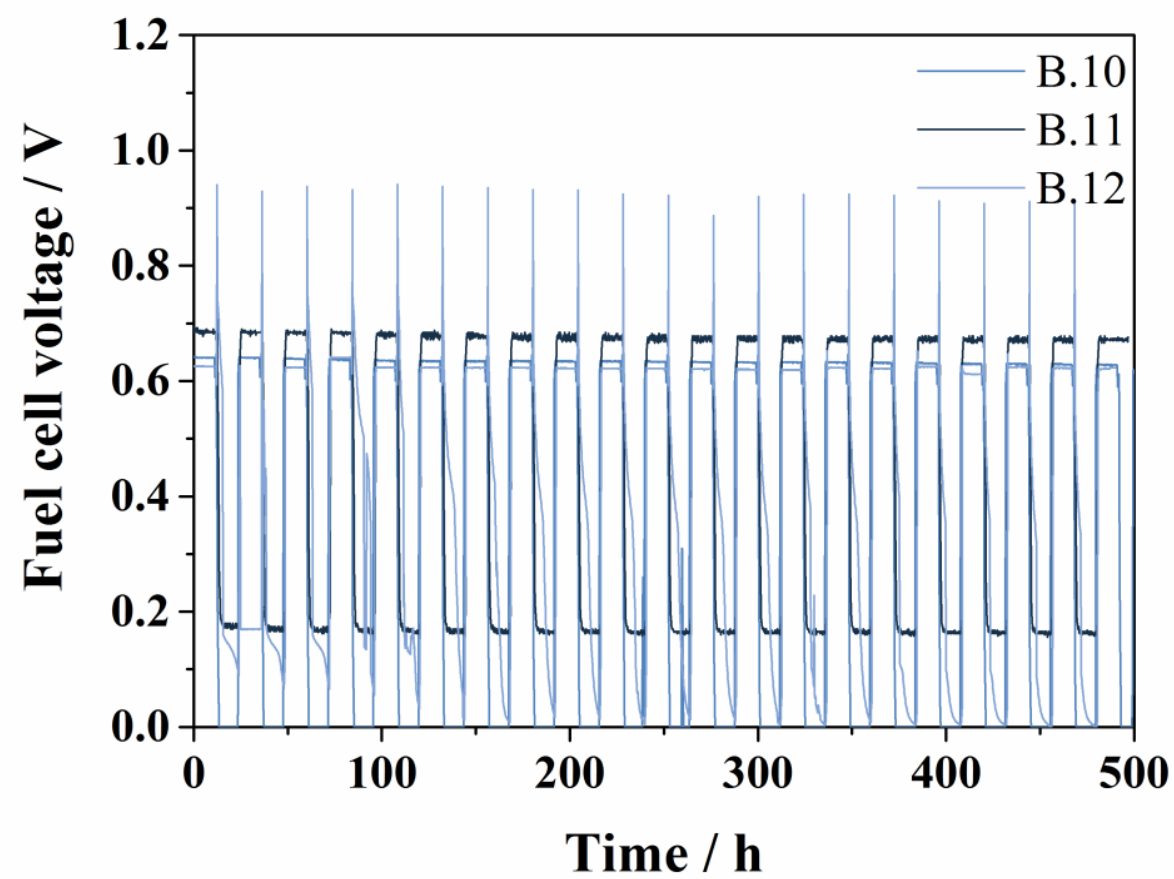

Figure 7: Voltage as function of time, start/stop cycling test; manufacturer B.

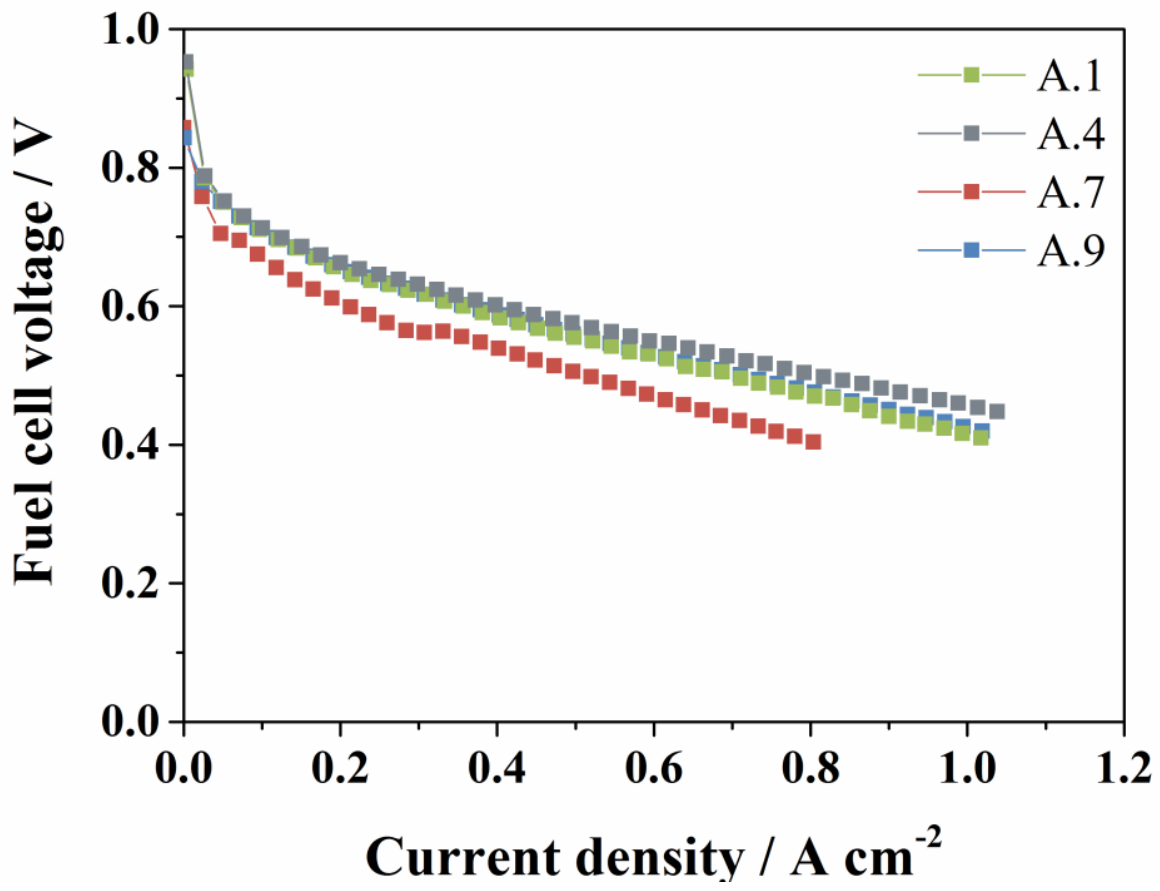

Figure 8: Polarisation curves under $\mathrm{H}_{2}$ and air at BoL, rapid test, manufacturer A. 


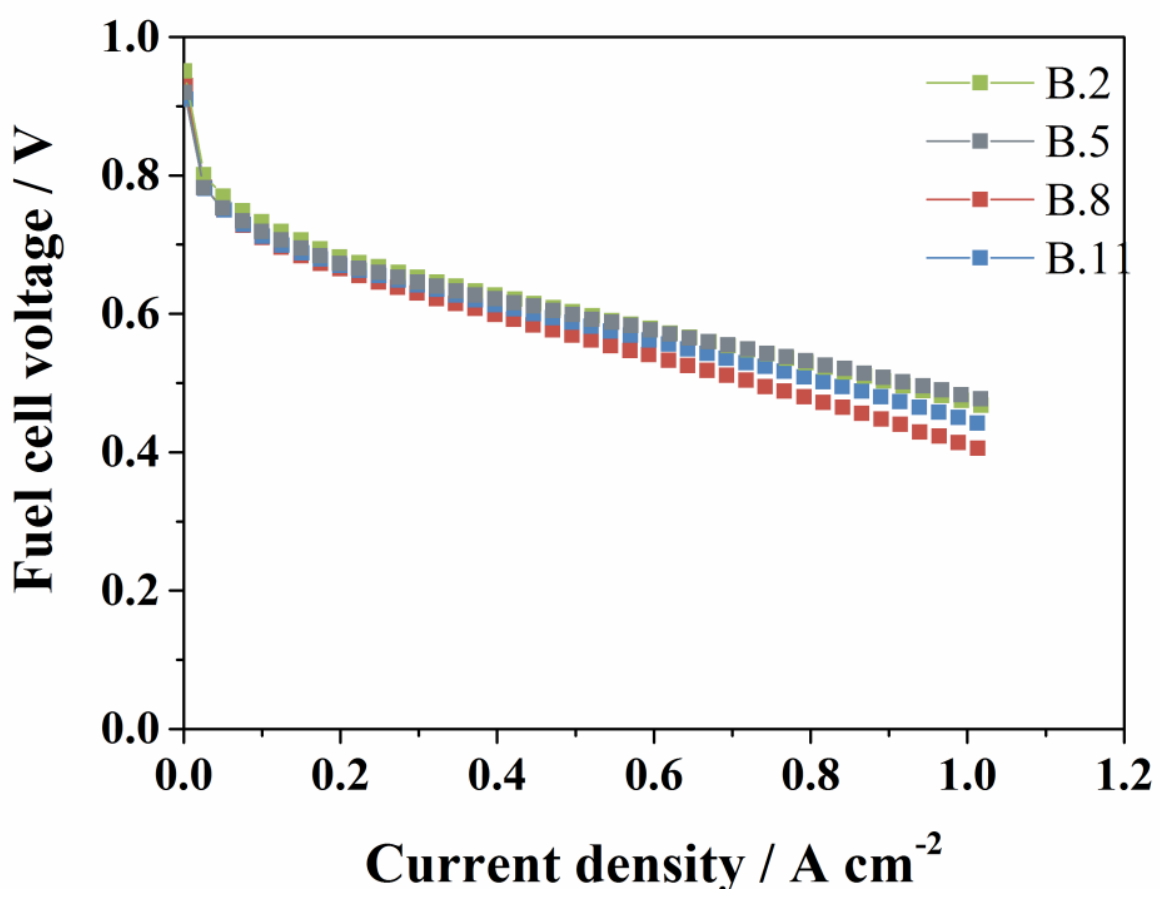

Figure 9: Polarisation curves under $\mathrm{H}_{2}$ and air at BoL, rapid test, manufacturer B.

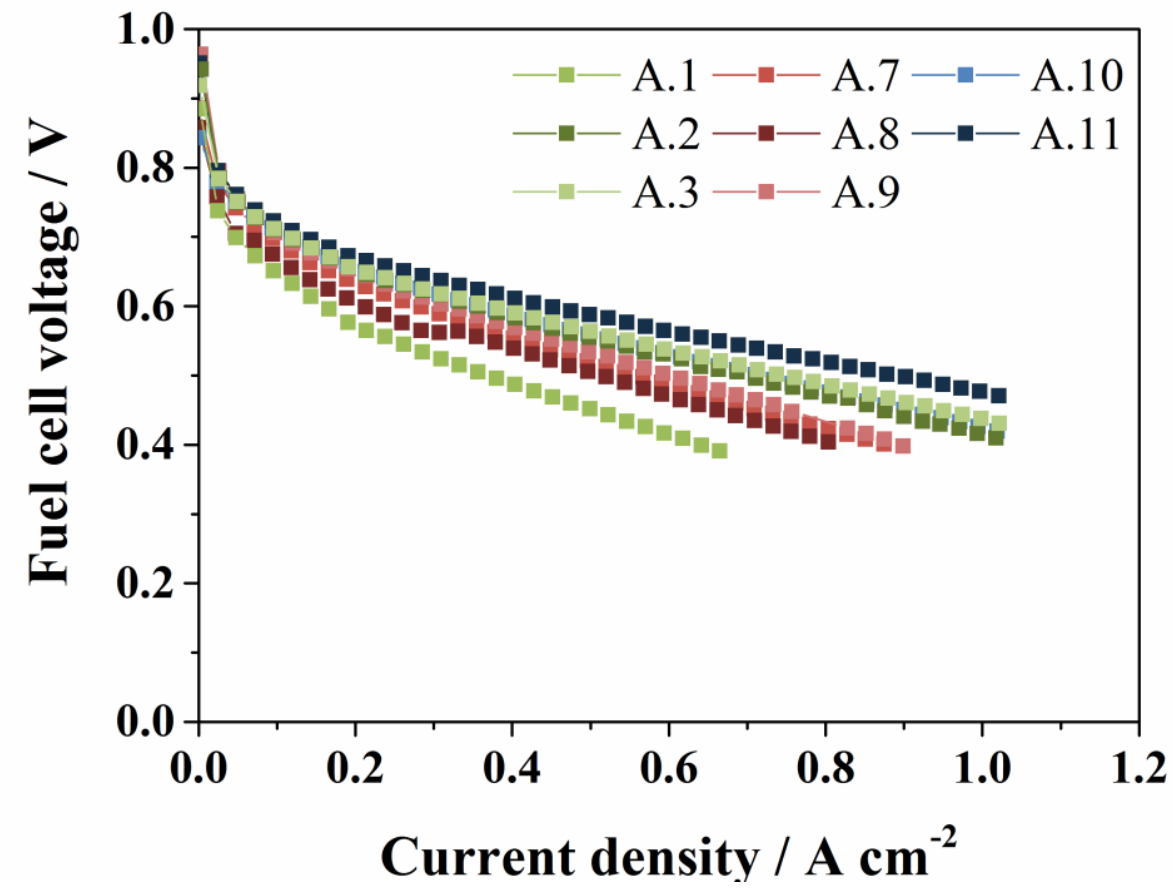

Figure 10: Polarisation curves under $\mathrm{H}_{2}$ and air at BoL, load cycling test, manufacturer $\mathrm{A}$. 


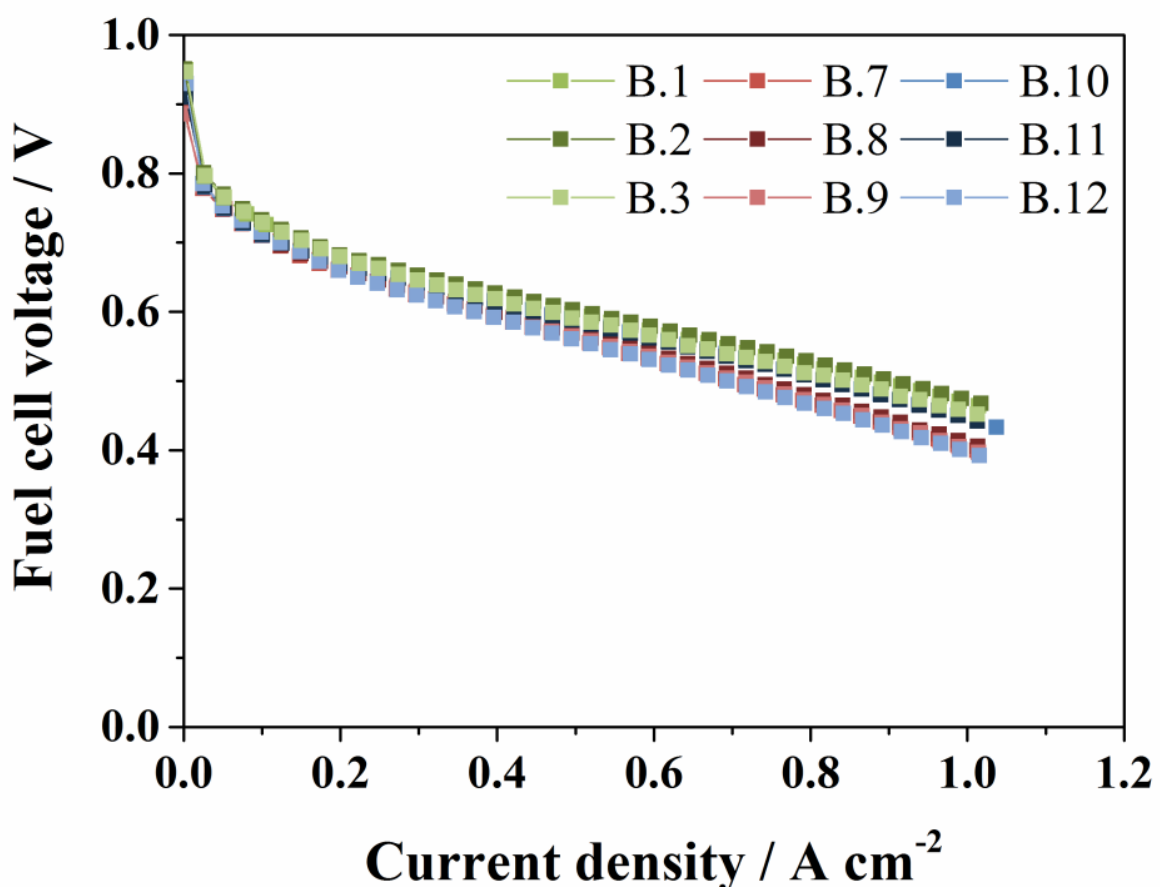

Figure 11: Polarisation curves under $\mathrm{H}_{2}$ and air at BoL, load cycling test, manufacturer $\mathrm{B}$.

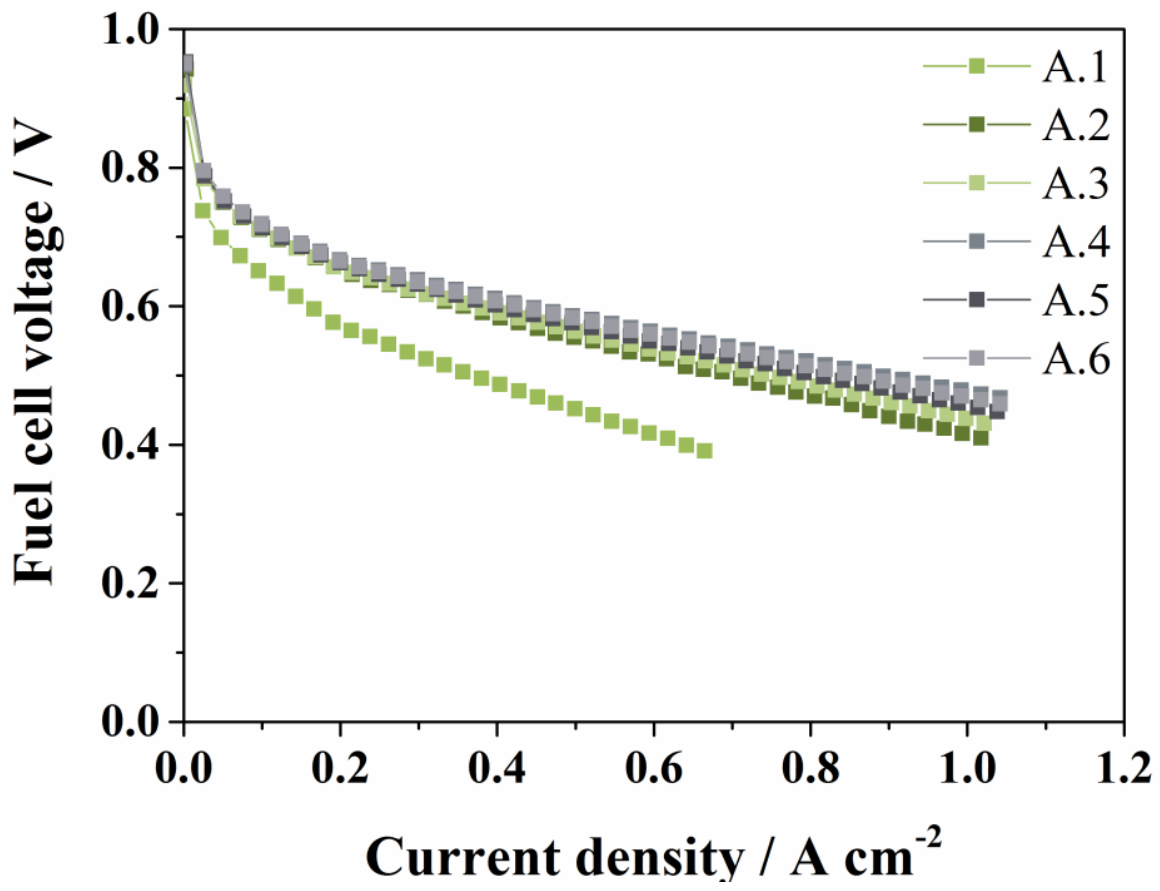

Figure 12: Polarisation curves under $\mathrm{H}_{2}$ and air at BoL, start/stop cycling test, manufacturer A. 


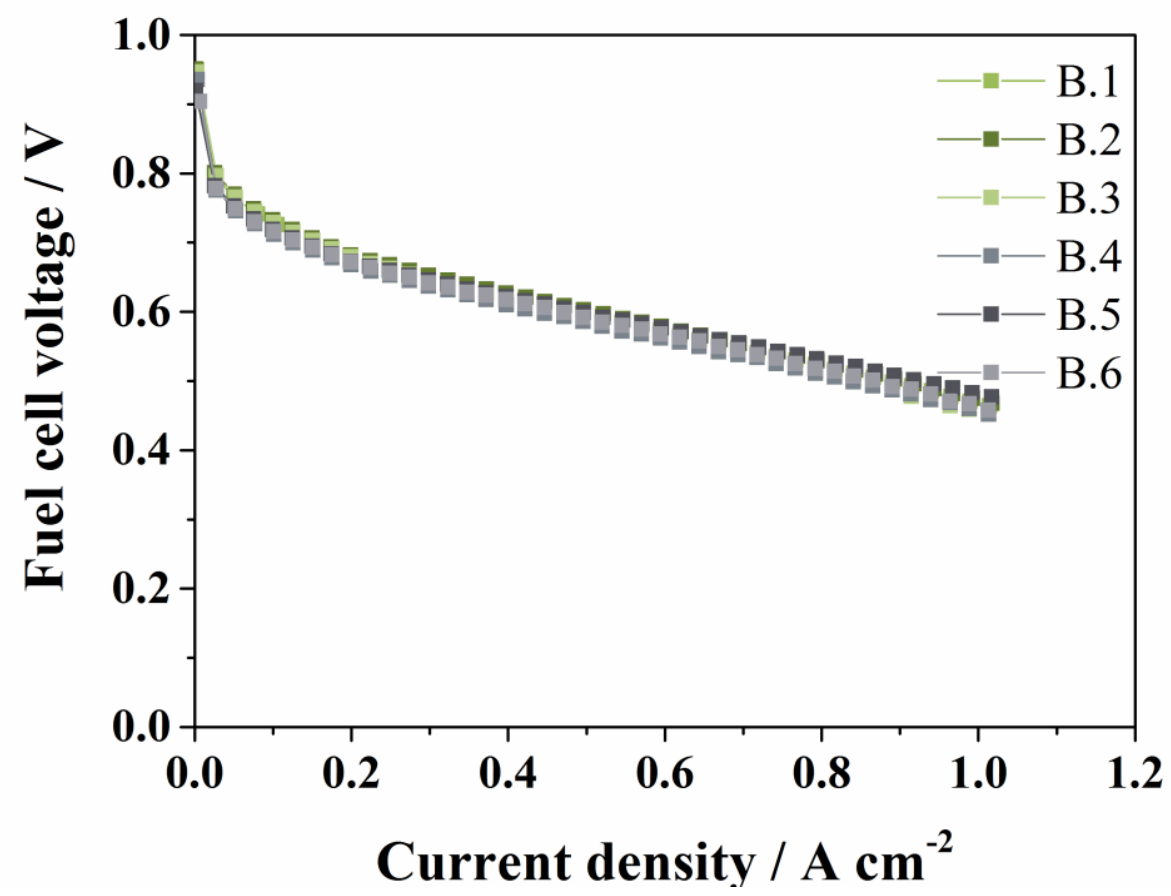

Figure 13: Polarisation curves under $\mathrm{H}_{2}$ and air at BoL, start/stop cycling test, manufacturer B.

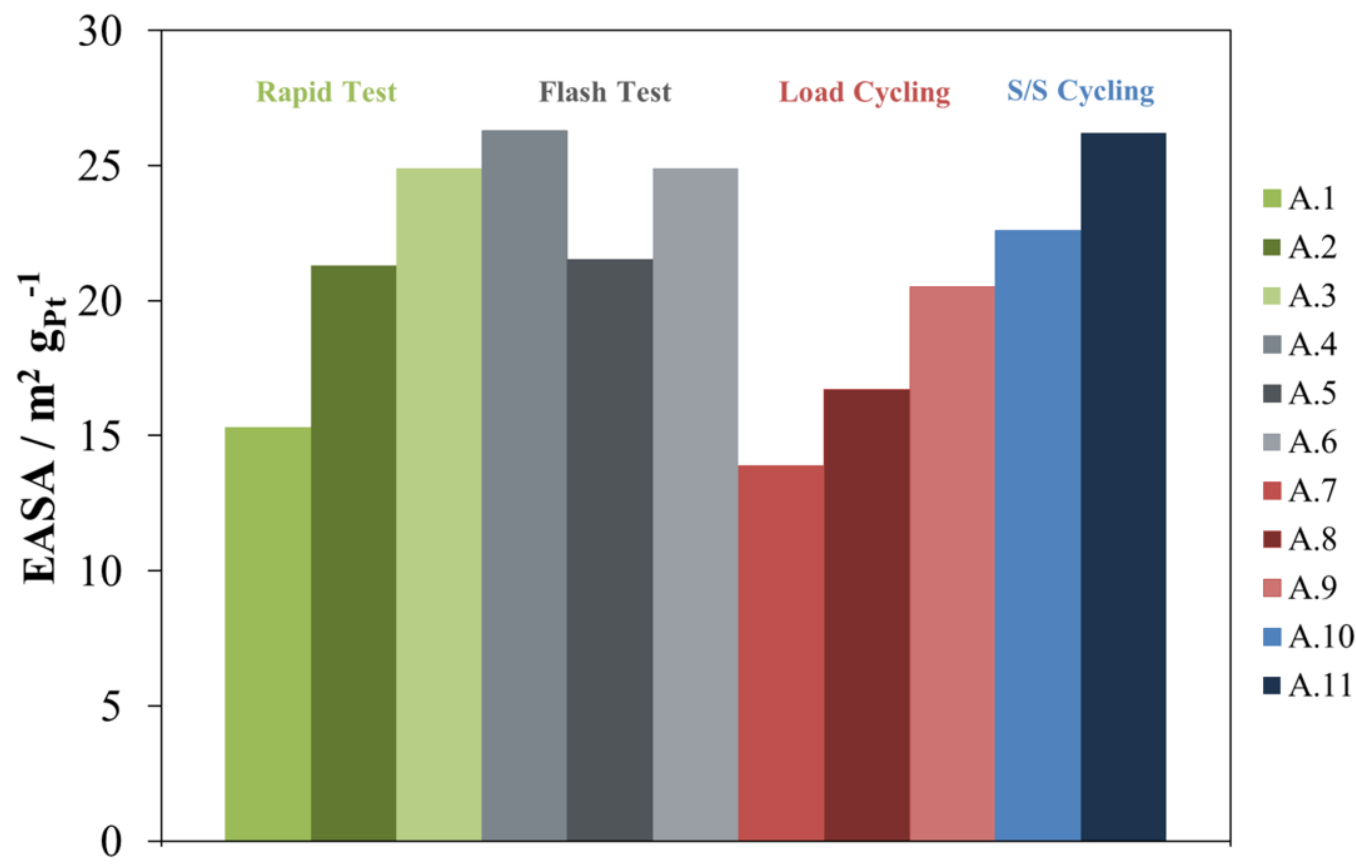

Figure 14: Electrochemical active surface area (EASA) at BoL; MEAs of manufacturer A. 


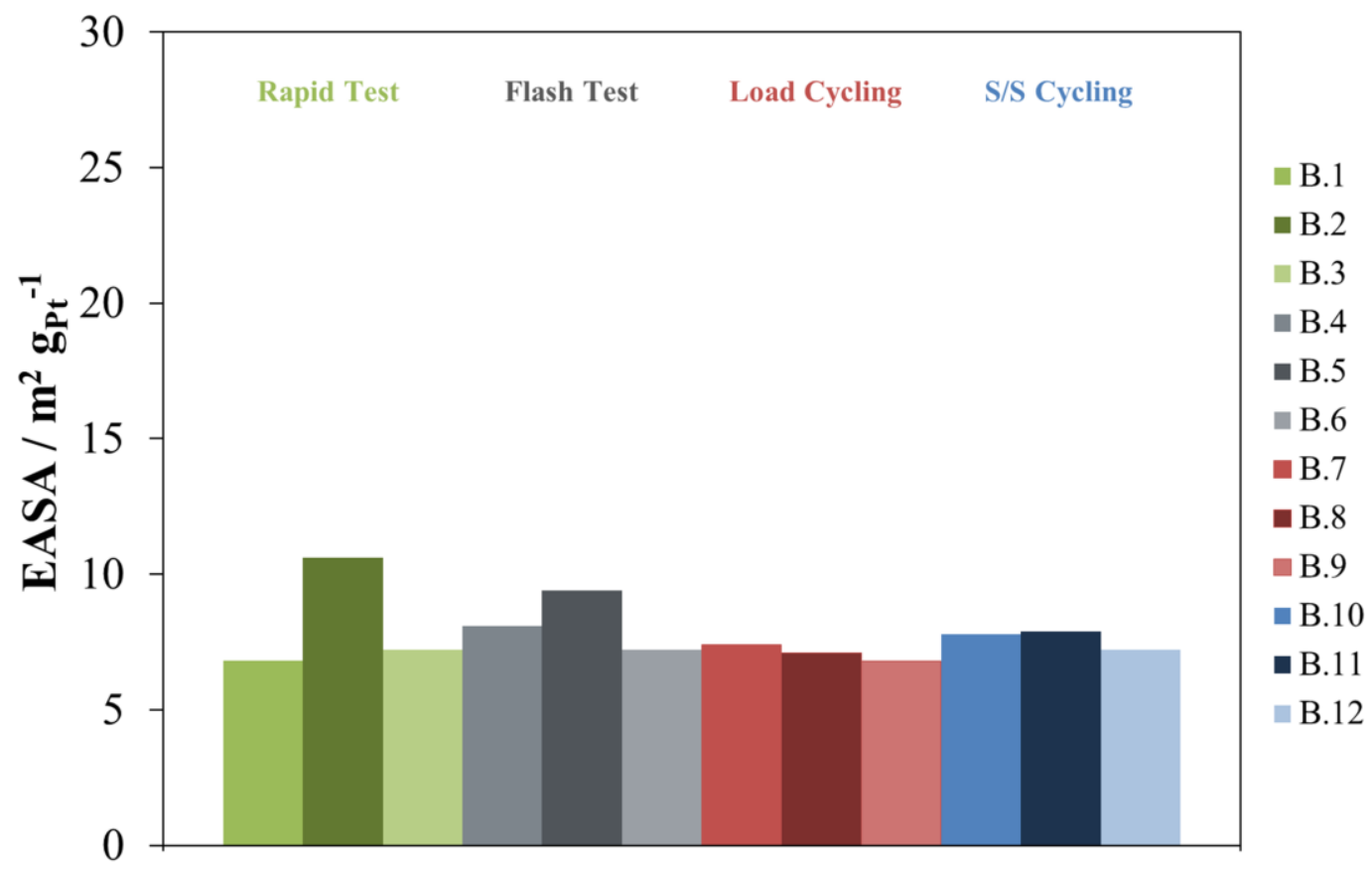

Figure 15: Electrochemical active surface area (EASA) at BoL; MEAs of manufacturer B.

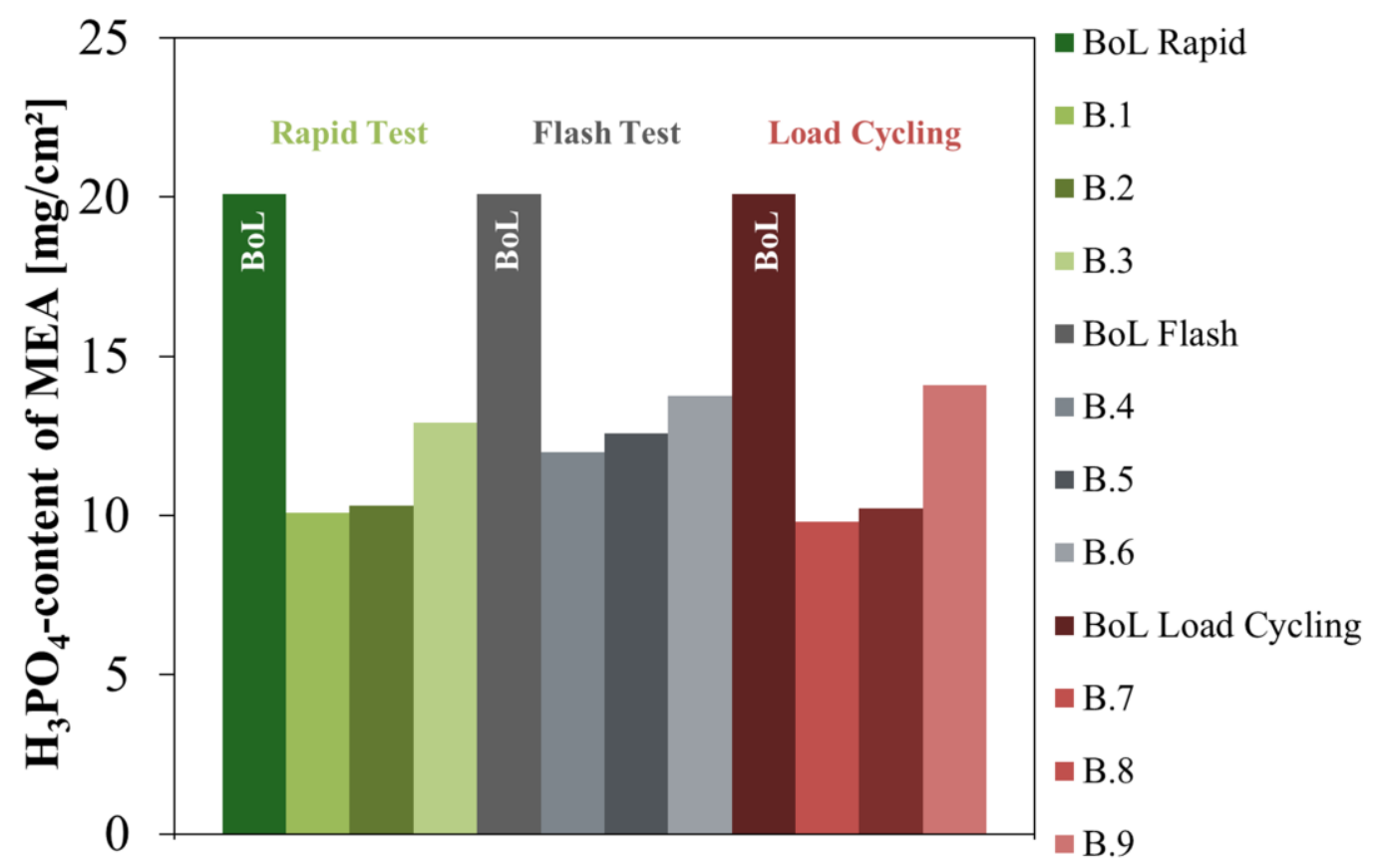

Figure 16: $\mathrm{H}_{3} \mathrm{PO}_{4}$ content of MEAs type $\mathrm{B}$, ante- and post-mortem. 


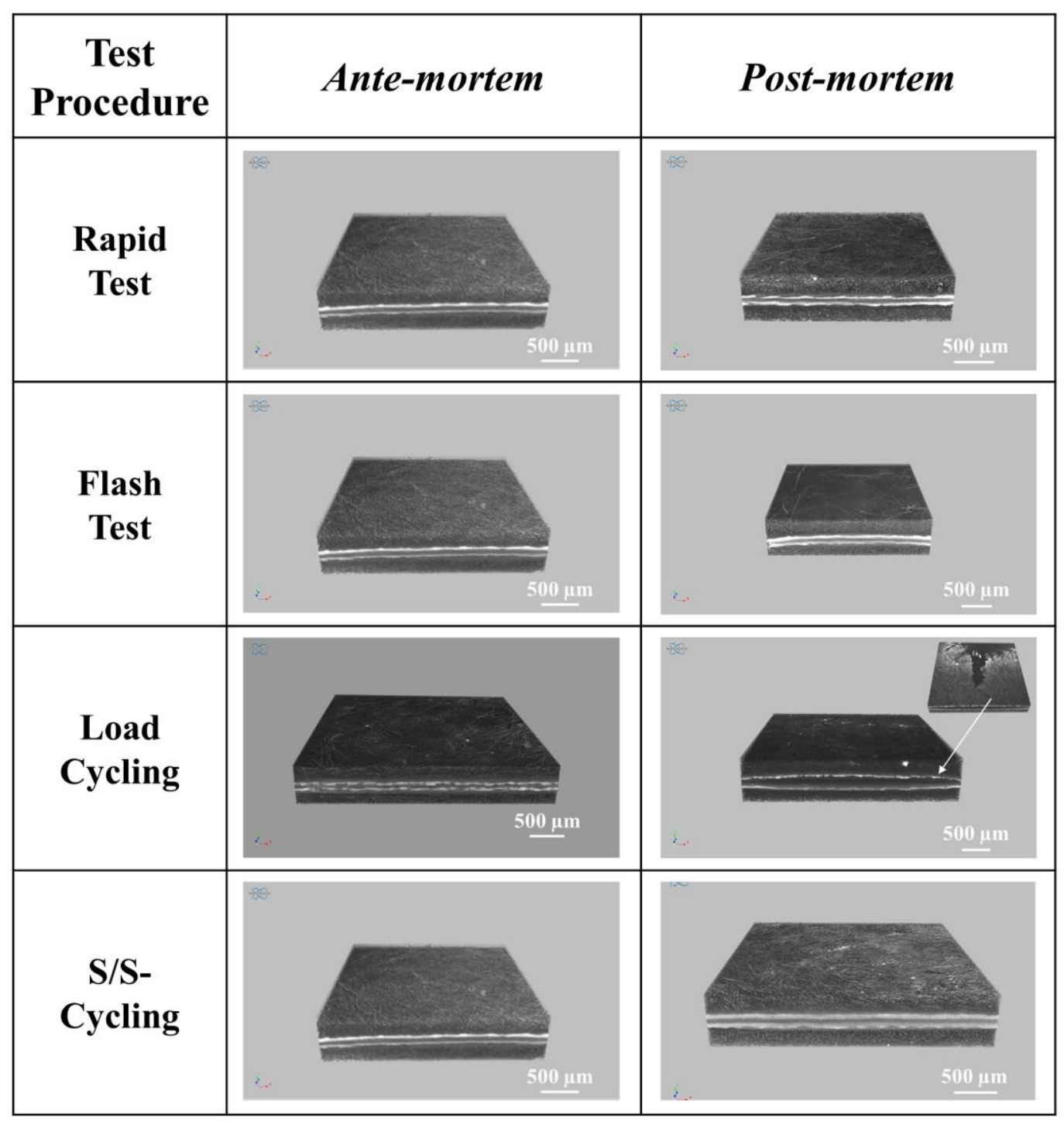

Figure 17: 3D- $\mu$-CT-images of MEAs type A. 


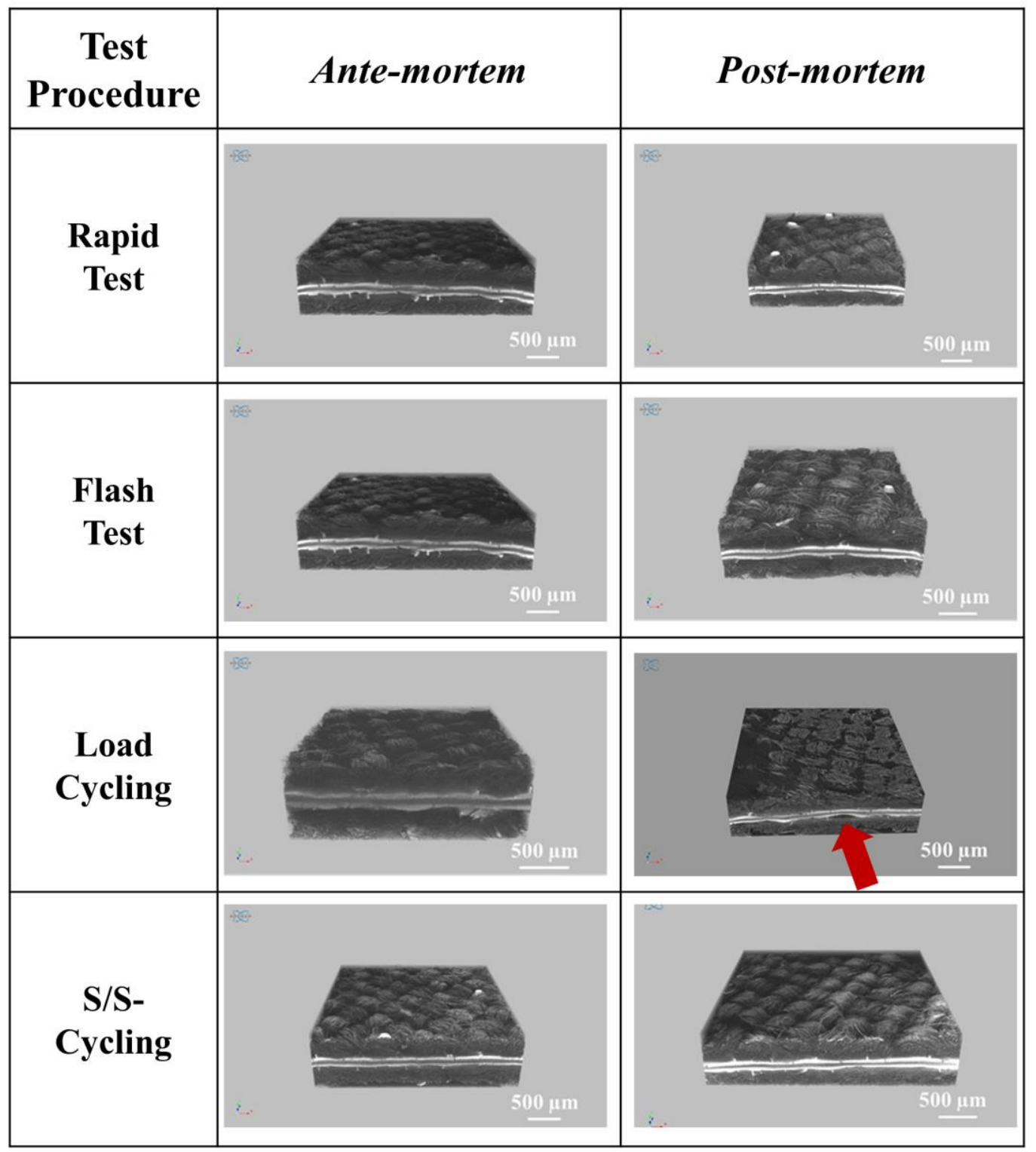

Figure 18: 3D- $\mu$-CT-images of MEAs type B. 
Table Captions

Table 1: $\mu$-CT operational parameter.

\begin{tabular}{|c|c|c|}
\hline Parameter & Value & Unit \\
\hline Acceleration voltage & $78-82$ & $\mathrm{kV}$ \\
\hline Source Current & $96-102$ & $\mu \mathrm{A}$ \\
\hline Sample size $\varnothing$ & $4-5$ & $\mathrm{~mm}$ \\
\hline Rotation step & 0.2 & $\circ$ \\
\hline Random movement & 10 & - \\
\hline Averaging & 4 & - \\
\hline Optical resolution & $1.30-2.19$ & $\mu \mathrm{m} / \mathrm{px}$ \\
\hline Duration & $140-180$ & $\mathrm{~min}$ \\
\hline
\end{tabular}

Table 2: Degradation rates of MEAs of manufacturer A and B operated under load cycling or start/stop cycling conditions at different current densities.

\begin{tabular}{|c|c|c|c|c|}
\hline \multirow{2}{*}{ Test procedure } & \multirow{2}{*}{ MEA } & \multicolumn{3}{|c|}{ Degradation rates / $\mu \mathrm{Vh}^{-1}$} \\
\hline & & $@ 0.3 \mathrm{~A} \mathrm{~cm}^{-2}$ & $@ 0.6 \mathrm{~A} \mathrm{~cm}^{-2}$ & $@ 1.0 \mathrm{~A} \mathrm{~cm}^{-2}$ \\
\hline \multirow{6}{*}{ Load Cycling } & A.7 & -96 & -228 & -330 \\
\hline & A. 8 & -53 & -144 & -314 \\
\hline & A.9 & -58 & -144 & -448 \\
\hline & B.7 & +2 & -36 & -129 \\
\hline & B.8 & -32 & -48 & -68 \\
\hline & B.9 & -10 & -13 & -18 \\
\hline \multirow{5}{*}{ Start/Stop-Cycling } & A.10 & -73 & & \\
\hline & A.11 & -128 & & \\
\hline & B. 10 & -33 & & \\
\hline & B.11 & -34 & & \\
\hline & B. 12 & -9 & & \\
\hline
\end{tabular}


Table 3: Thicknesses of MEA-layer, ante- and post-mortem, determined by $\mu$-CT investigations (Dataviewer).

\begin{tabular}{|c|c|c|c|c|c|c|c|}
\hline \multirow[b]{2}{*}{$\begin{array}{c}\text { Test } \\
\text { procedure }\end{array}$} & \multirow[b]{2}{*}{ MEA No. } & \multicolumn{6}{|c|}{ Layer thickness / $\mu \mathrm{m}$} \\
\hline & & $\begin{array}{c}\text { GDL } \\
\text { cathode }\end{array}$ & $\begin{array}{c}\text { CL } \\
\text { cathode }\end{array}$ & Membrane & $\begin{array}{c}\text { CL } \\
\text { anode }\end{array}$ & $\begin{array}{c}\text { GDL } \\
\text { anode }\end{array}$ & Total \\
\hline \multirow{4}{*}{$\begin{array}{l}\text { Rapid test } \\
(2.2 .4)\end{array}$} & $\begin{array}{c}\text { BoL A } \\
\text { Batch } 1\end{array}$ & $\begin{array}{c}223 \\
\pm 14\end{array}$ & $\begin{array}{c}34 \\
\pm 6\end{array}$ & $\begin{array}{l}68 \\
\pm 7\end{array}$ & $\begin{array}{c}31 \\
\pm 4\end{array}$ & $\begin{array}{c}208 \\
\pm 8\end{array}$ & $\begin{array}{l}573 \\
\pm 11\end{array}$ \\
\hline & A. 1 & $\begin{array}{r}239 \\
\pm 14\end{array}$ & $\begin{array}{l}23 \\
\pm 6\end{array}$ & $\begin{array}{l}56 \\
\pm 7\end{array}$ & $\begin{array}{r}34 \\
\pm 9\end{array}$ & $\begin{array}{l}231 \\
\pm 19\end{array}$ & $\begin{array}{c}588 \\
\pm 20\end{array}$ \\
\hline & $\begin{array}{l}\text { BoL B } \\
\text { Batch } 1\end{array}$ & $\begin{array}{r}304 \\
\pm 34\end{array}$ & $\begin{array}{r}44 \\
\pm 9\end{array}$ & $\begin{array}{r}68 \\
\pm 6\end{array}$ & $\begin{array}{l}41 \\
\pm 8\end{array}$ & $\begin{array}{r}299 \\
\pm 48\end{array}$ & $\begin{array}{r}760 \\
\pm 59\end{array}$ \\
\hline & B. 1 & $\begin{array}{r}316 \\
\pm 37 \\
\end{array}$ & $\begin{array}{c}38 \\
\pm 18\end{array}$ & $\begin{array}{r}60 \\
\pm 7\end{array}$ & $\begin{array}{c}34 \\
\pm 10 \\
\end{array}$ & $\begin{array}{r}305 \\
\pm 40 \\
\end{array}$ & $\begin{array}{r}742 \\
\pm 55\end{array}$ \\
\hline \multirow{4}{*}{$\begin{array}{c}\text { Flash test } \\
\quad(2.2 .5)\end{array}$} & $\begin{array}{c}\text { BoL A } \\
\text { Batch 1 }\end{array}$ & $\begin{array}{l}223 \\
\pm 14\end{array}$ & $\begin{array}{c}34 \\
\pm 6\end{array}$ & $\begin{array}{l}68 \\
\pm 7\end{array}$ & $\begin{array}{c}31 \\
\pm 4\end{array}$ & $\begin{array}{c}208 \\
\pm 8\end{array}$ & $\begin{array}{l}573 \\
\pm 11\end{array}$ \\
\hline & A. 5 & $\begin{array}{r}236 \\
\pm 19 \\
\end{array}$ & $\begin{array}{r}40 \\
\pm 7 \\
\end{array}$ & $\begin{array}{r}69 \\
\pm 7 \\
\end{array}$ & $\begin{array}{l}41 \\
\pm 9 \\
\end{array}$ & $\begin{array}{r}247 \\
\pm 22 \\
\end{array}$ & $\begin{array}{r}612 \\
\pm 25 \\
\end{array}$ \\
\hline & $\begin{array}{l}\text { BoL B } \\
\text { Batch } 1\end{array}$ & $\begin{array}{r}304 \\
\pm 34 \\
\end{array}$ & $\begin{array}{r}44 \\
\pm 9 \\
\end{array}$ & $\begin{array}{r}68 \\
\pm 6 \\
\end{array}$ & $\begin{array}{l}41 \\
\pm 8 \\
\end{array}$ & $\begin{array}{r}299 \\
\pm 48 \\
\end{array}$ & $\begin{array}{r}760 \\
\pm 59 \\
\end{array}$ \\
\hline & B.4 & $\begin{array}{r}319 \\
\pm 54 \\
\end{array}$ & $\begin{array}{l}42 \\
\pm 6 \\
\end{array}$ & $\begin{array}{r}63 \\
\pm 7 \\
\end{array}$ & $\begin{array}{r}43 \\
\pm 9 \\
\end{array}$ & $\begin{array}{r}305 \\
\pm 31 \\
\end{array}$ & $\begin{array}{r}770 \\
\pm 73 \\
\end{array}$ \\
\hline \multirow{4}{*}{$\begin{array}{c}\text { Load } \\
\text { cycling } \\
(2.2 .6)\end{array}$} & $\begin{array}{c}\text { BoL A } \\
\text { Batch } 2\end{array}$ & $\begin{array}{l}233 \\
\pm 12\end{array}$ & $\begin{array}{l}28 \\
\pm 5\end{array}$ & $\begin{array}{l}55 \\
\pm 6\end{array}$ & $\begin{array}{l}29 \\
\pm 7\end{array}$ & $\begin{array}{l}252 \\
\pm 17\end{array}$ & $\begin{array}{l}582 \\
\pm 15\end{array}$ \\
\hline & A.7 & $\begin{array}{r}230 \\
\pm 14 \\
\end{array}$ & $\begin{array}{r}22 \\
\pm 6 \\
\end{array}$ & $\begin{array}{l}51 \\
\pm 8 \\
\end{array}$ & $\begin{array}{r}28 \\
\pm 8 \\
\end{array}$ & $\begin{array}{r}229 \\
\pm 11 \\
\end{array}$ & $*$ \\
\hline & $\begin{array}{c}\text { BoL B } \\
\text { Batch } 2\end{array}$ & $\begin{array}{r}323 \\
\pm 31 \\
\end{array}$ & $\begin{array}{c}37 \\
\pm 18 \\
\end{array}$ & $\begin{array}{c}75 \\
\pm 12 \\
\end{array}$ & $\begin{array}{l}31 \\
\pm 4\end{array}$ & $\begin{array}{r}304 \\
\pm 30 \\
\end{array}$ & $\begin{array}{r}769 \\
\pm 55 \\
\end{array}$ \\
\hline & B.7 & $\begin{array}{r}315 \\
\pm 46 \\
\end{array}$ & $\begin{array}{r}44 \\
\pm 8 \\
\end{array}$ & $\begin{array}{l}52 \\
\pm 8 \\
\end{array}$ & $\begin{array}{c}43 \\
\pm 16 \\
\end{array}$ & $\begin{array}{r}312 \\
\pm 50 \\
\end{array}$ & $\begin{array}{c}744 \pm \\
52 \\
\end{array}$ \\
\hline \multirow{4}{*}{$\begin{array}{c}\text { Start/stop } \\
\text { cycling } \\
(2.2 .7)\end{array}$} & $\begin{array}{l}\text { BoL A } \\
\text { Batch } 1\end{array}$ & $\begin{array}{l}223 \\
\pm 14\end{array}$ & $\begin{array}{l}34 \\
\pm 6\end{array}$ & $\begin{array}{r}68 \\
\pm 7\end{array}$ & $\begin{array}{c}31 \\
\pm 4\end{array}$ & $\begin{array}{c}208 \\
\pm 8\end{array}$ & $\begin{array}{c}573 \\
\pm 11\end{array}$ \\
\hline & A. 10 & $\begin{array}{l}221 \\
\pm 11 \\
\end{array}$ & $\begin{array}{r}46 \\
\pm 7\end{array}$ & $\begin{array}{r}50 \\
\pm 9 \\
\end{array}$ & $\begin{array}{l}47 \\
\pm 6 \\
\end{array}$ & $\begin{array}{r}234 \\
\pm 20 \\
\end{array}$ & $\begin{array}{r}595 \\
\pm 17 \\
\end{array}$ \\
\hline & $\begin{array}{c}\text { BoL B } \\
\text { Batch } 3\end{array}$ & $\begin{array}{r}320 \\
\pm 23 \\
\end{array}$ & $\begin{array}{r}40 \\
\pm 9 \\
\end{array}$ & $\begin{array}{r}64 \\
\pm 7 \\
\end{array}$ & $\begin{array}{c}38 \\
\pm 10 \\
\end{array}$ & $\begin{array}{r}304 \\
\pm 42 \\
\end{array}$ & $\begin{array}{r}784 \\
\pm 40 \\
\end{array}$ \\
\hline & B.11 & $\begin{array}{r}311 \\
\pm 36 \\
\end{array}$ & $\begin{array}{r}36 \\
\pm 13 \\
\end{array}$ & $\begin{array}{c}59 \\
\pm 11 \\
\end{array}$ & $\begin{array}{c}40 \\
\pm 13 \\
\end{array}$ & $\begin{array}{r}321 \\
\pm 34 \\
\end{array}$ & $\begin{array}{r}762 \\
\pm 51 \\
\end{array}$ \\
\hline
\end{tabular}

*Not shown due to delamination effects. 